\title{
Revista Colombiana de Obstetricia y Ginecología
}

ORGANO DE LA SOCIEDAD COLOMBIANA DE OBSTETRICIA Y GINECOLOGIA

Administrador: JUAN N. BAQUERO - Apartado Nacional 276 - Carrera 7a., número 12-80 - Oficina No. 23

Volumen II - Bogotá, Colombia - Diciembre · Enero de 1950/51 - Número 1

\section{Nueva Directiva}

La nueva Directiva de la Sociedad Colombiana de Obstetricia y Ginecología, al iniciar sus funciones, felicita a la Directiva saliente por su labor en todo sentido meritoria. Al tiempo invita a todos los miembros de la Sociedad a tomar parte activa en lo que redunde en beneficio y progreso de esta: en lo ético, científico, intelectual, gremial y técnico.

Es propósito de la nueva Directiva incrementar la labor científica en sus sesiones, ya que en los últimos tiempos elia ha sido casi anulada por los problemas originados con el establecimiento del Seguro Social Obligatorio en Colombia. En ese propósito aspira a que los temas tratados revistan la mayor sencillez posible, aunque no sean de investidura altamente académica; que quien tenga una historia cĺnica, que le atribuya interés obstétrico o ginecológico, no tenga vacilación en presentarla, a pesar de que no sea un voluminoso y documertado trabajo científico.

Además, tiene el proyecto de agrandar la organización de la Sociedad que ha crecido naturalmente en sus ocho años de vida: la Revista tendrá dos valiosos elementos en su redacción, independientes a los miembros de la Directiva; figurará en cada número un relato del tema científico analizado en las deliberaciones; habrá que fomentar y aumentar los canjes e intercambios con las revistas científicas de otros países y del nuestro; babrá que pensar si es conveniente adquirir un local propio, donde opere una Oficina de Información y Organización, con dirección precisa, apartados aéreo y nacional, Biblioteca, Archivador y Kárdex donde aparezcan los títulos y obra científica o profesional de los socios, y que sea la sede donde deba reunirse la Directiva, por lo menos dos veces al mes, para atender las diferentes actividades de la Institución.

Ojalá que nuestras intenciones se conviertan en realidad y que si surgen dificultades todos se presenten a obviarlas, o la Directiva que nos reemplace en el futuro. 


\section{Al servicio de la medicina humana}

Clarence Finlayson quejábase con abundancia de razones del triunfo de la máquina sobre el hombre, y al estudiar las raíces de la tragedia que amenaza desquiciar al mundo, hablaba en severo ensayo filosófico de cómu la educación al despreciar el hálito humanista, en vez de técnicos, preparaba hombres de recortados horizontes. El médico que sólo sabe su especialidad, ni médico es, dice un adagio repleto de sabiduría. Por eso la Revista de la Sociedad Colombiana de Obstetricia y Ginecología dedica unas de sus páginas a esos problemas que suscitan controversia y despiertan inquietudes.

Cuando se habla del aborto criminal surge la protesta airada, los vocablos condenatorios cúbrense de apocalípticos atuen. dos; mas si la censura llueve sobre quien trocó los blasones de abroquelada hidalguía por desmirriados escudos sin cuarteles de grandeza, hay quien olvida que no es libre de responsabilidad moral si niega el concurso para la extemporánea terminación de un embarazo, pero señala nombres de quienes sin el menor reato, por no tener sentido ético die la existencia, viven gozosos de tan mezquinos menesteres.

Así como "para penetrar el misterio de las profundidades se necesita a veces contemplar las cimas", al decir de Bergson, respecto de los problemas de la medicina y de la moral preciso es levantar los ojos y la mente hacia las cumbres vaticanas. S. S. Pío XI, en inmortal encíclica, que debería figurar en la bilioteca de todo médico culto, anotaba que la Iglesia levanta muy alta la voz entre las ruinas morales para decir cuál es el camino sendero de la perfección. El médico no puede sustraerse a la estupenda lucha y sentirse neutral en la contienda. Tiene una misión más noble que la de corregir procesos químicos. Y sabido es que en el templo augusto de su consultorio y en la cabecera del enfermo vése abocado ante conflictos espirituales que ha de resol. ver conforme a dictados inmanentes en defensa de imprescrip- 
pleitesía inconsciente al criterio de autoridad, también las normas que animan las convicciones íntimas y la vida privada tienen que iluminar la conducta profesional y social.

Detrás de cada problema humano hay una cuestión teológica, dijo quien bien lo sabía por haber ganado las escalas de la sabiduría. $Y$ si bien es cierto que toda moral descansa en la noción de Dios, y que si El no existiera, lógica sería una cerril independencia frente a los valores humanos, como discurría en las páginas de Dostowiesky el personaje alumbrado por destellos de pesadumbre cósmica, el médico cristiano ha de saber que toda mutilación es gravemente ilícita si se persigue la esterilidad para que ésta procure el bien apetecido.

Trayendo a su memoria unos conceptos rubricados por la autoridad indiscutible de Tarnier, Ricaud comenta la esterilidad terapéutica. Después de castigar con frases respaldadas en un firme conocimiento de las cosas las tendencias del mundo contemporáneo con sus lacras invasoras del marco familiar, estigmatizadas ya en esta Revista por el Profesor Ramírez Merchán, refiérese a la mutilación. No es lícita, porque mediante la esterilidad se consigue el bien buscado. Y no valdría argüír que la eresterilidad no es querida por sí misma sino teniendo en mientes el hipotético peligrop, pues entonces sí estaríamos ante la más tremenda quiebra de la moral, defendiendo que el fin justifica los medios, máxima rechazada aun por los mismos que en este campo la aceptan pero la condenan en otros órdenes de la vida social y politica.

Cierto que el médico no es por esencia un moralista ni un director de conciencias. Empero, no debe olvidar que su profesión tiene miras humanas, que la materia con que trabaja no es simple almácigo de átomos sino un conjunto maravilloso iluminado por un principio espiritual. En todo debe observar que el individuo tiene derechos anteriores a la comunidad y que por encima del Estado y de los convencionalismos se yergue majestuosa la presencia de Dios.

RAMON FRANCISCO SANCHEZ 